\title{
THE CONTRIBUTION OF THE LEADER APPROACH TO THE DEVELOPMENT OF RURAL AREAS IN LATVIA
}

Armands Veveris ${ }^{1}$, Dr.oec.; Armands Puzulis ${ }^{2}$, Dr.geogr.

${ }_{1,2}$ Institute of Agricultural Resources and Economics, Latvia

\begin{abstract}
The study was conducted with a purpose to find out a present role of the LEADER approach in development of the Latvian rural areas. The article consists of analysis of the LEADER approach in Latvia and other European countries, historical development and previously carried out evaluations of the LEADER results, the quantitative results for 2014-2020 period of the LEADER approach in Latvia. The Local Development Strategies (LDS) were analysed. Although the major needs of local communities identified by LAGs are linked to labour possibilities, infrastructure, knowledge and information, more important contribution of the LEADER projects was made in infrastructure development and not in strengthening of economic development. Nevertheless, the LEADER approach itself shows good results in facilitation of the local activities and thus looks perspective in future. It would be useful to use the multi-fund approach for the LAG support, which would facilitate development of the strategies according to local (community) needs. The LEADER place in the local development method is challenging for the next period.
\end{abstract}

Key words: LEADER, rural development, local, evaluation. JEL code: R53, R58.

\section{Introduction}

Balanced development of the rural areas in Latvia is one of the main challenges in development facilitation of Latvia. One of approaches used in the EU for facilitation of the local development is the LEADER approach (the term CLLD is also used). This approach is being increasingly used also in Latvia, while there is still very little research done on its importance and efficiency. One of the reasons for it - the LEADER results are hard to quantify. Yet, they may still be quantified at least partially, applying various indicators, characterizing investments and also results. The purpose of this paper is to provide an overview on the current role and results of the LEADER/CLLD approach in development of the rural areas in Latvia.

In order to reach the aim, the following tasks were established for the study:

- Provide an insight in the nature and development of the LEADER approach in the EU and Latvia, and in previously carried out evaluation;

- analyse importance of LEADER in the current (2014-2020) planning period and its main results;

- formulate conclusions and recommendations for further use of LEADER.

The hypothesis set for this study is that the LEADER/CLLD approach may be successful for stimulation of the local development and in general has successfully proven itself in the course of the RDP implementation.

Qualitative and quantitative economic research methods: analysis and synthesis; comparative analysis, logically and abstractly constructive methods were used in the study, performing analysis of various scientific publications, laws and regulations, documents, programmes and information sources. Novelty of the paper is linking to quantification of the LEADER results and analysis of results of the most recent (2014-2020) period. Limited format of the article affects more detailed review of the subject. Only some quantitative indicators have been reviewed due to this reason.

\footnotetext{
${ }^{1}$ Researcher, Institute of Agricultural Resources and Economics, Latvia
} 


\section{Research results and discussion}

\section{Nature of the LEADER approach and research carried out on it}

LEADER can be defined as purposeful and mutually coordinated activities for facilitation of rural development. The LEADER approach is being used in the EU since 1999. This is a method for facilitation of location-based initiatives having economic, social and administration component. The approach is based on 7 principles: area - based local development strategies, bottom - up elaboration and implementation of strategies, local public - private partnerships - local action groups, integrated and multi-sector actions, innovation, cooperation and networking (EC Regulation 1698/2005). The EU implements this approach by using the Rural Development Programmes (RDP). Several approach implementation stages exist in the EU - LEADER I (1991-1993), LEADER II (19941999), LEADER+ (2000-2006), "LEADER axis” (2007-2013), CLLD (2014-2020). Community-Led Local Development (CLLD) is being attributed to other funds and measures; the LEADER method is used in several varieties also in the cities. The LEADER approach is in the context with the development of local communities.

The LEADER approach is currently being considered as a neo-endogenous development tool that includes internal - local and external - a sum of factor and network interaction to assess and use local resources (Bosworth et al., 2015).

Many studies have been carried out on the LEADER role in EU countries, which have been analysed and summarized in many publications (Pollermann et al., 2014a,2014b, Thuesen et al., 2014 etc.), where the publications up to 2013 can be found. The positive LEADER impact is being linked to a better cooperation, participation, networking, innovations, knowledge, activity of local people; the negative critique is being expressed regarding the top-down approach, proportion of the public sector (especially during the period of 2017-2013), allocation of power in decision-making, increase of bureaucratization, lack of innovations, low local social capital. It is recognized that the LEADER impact may not be generalized, since the circumstances and situations are very different (Pollermann et al., 2014b).

The impact analysis articles are still not very often to be found. The publications are often based on numbers, characterizing the outcome or result indicators, or the assessment is based on the results of surveys, qualitative data, which may be quantified to a very little extent. It is partially determined by the fact that the LEADER approach as such is mostly directed at the indicators that can be measured in terms of quantity, for example, the LEADER value added, assessment of 7 basic principle implementation (Thuesen et al., 2014 etc.). Partially it is determined by the critique on moving of LEADER away from the "bottom-up approach" itself, by replacing implementation of locally-based needs with subordination to top-down measures (Pollermann et al., 2014a). "Downup"' approach is being used, which is a term for the existing transformation of the LEADER approach, increasing the role of the "Top-down" and State-regulated institutions in the implementation process of the LEADER approach. Ignoring of these facts can affect the result, which expresses itself in formal assessment of the project outcome, while it tells very little about the LEADER approach itself and efficiency of its implementation.

The LEADER analysis has so far not been very widespread in Latvia. Studies look at the LEADER implementation in 2007-2013 - economic assessment (Krievina et al., 2015), implementation of the LEADER approach during initial stage (Svanberga, L., 2009; Svanberga, L., Radvila, J., 2007), Analysis of Social Innovations and Partnerships (Paula, L., Zobena, A., 2007). 
Several articles emphasizing low use of the local potential may be attributed to a situation currently in Latvia (Dargan et al., 2008, etc.); role and leadership of the local authority is especially significant in successful implementation of the LEADER approach (Marquardt, et al. 2012), based on the neo-endogenous development - creation of cooperation networks (Salemink et al., 2016).

When assessing the role of LEADER, it is important to understand where and what type of jobs are created, whether generation or redistribution of wealth is taking place; long-term management of state-level local processes is of essence, ownership matters, knowledge and understanding regarding the LEADER work, its success and misfortunes are also important topics (Shortall, S., 2004). It means formation of a deeper understanding regarding results achieved by LEADER. Role of the local community in the Development context is not related to growth, increased number of created jobs, but to formation of the community capacity, viability, self-reliance, joint actions (Cavaye, J.).

On the other hand, the LEADER approaches are directed at stimulation of economic processes more than at the investments, including on the administrative level, flexible partnership, strategic vision (Jankovic, 2012). The LEADER's organized LAGs and their importance play a significant role here (Vrabkova et al., 2017).

The role of LAG in the implementation of the LEADER approach has changed during the course of time. Projects become more politically controlled, standardized and administrated, but the independent organizations become 'Quangos' (quasi-non-governmental organizations) (Bruckmeier, 2000), becoming a part of the state project administrating system. Even though the analysis was carried out for the LEADER II period, as shown by other publications, it is still being very topical.

During the next period 2021-2027, the discussions on the LEADER role are handled in the smart villages context.

We can conclude in general that the LEADER role in the Development processes must be assessed broader that just economic or financial gains. The processes themselves and their depth rooted in the understanding of local people regarding the processes, their acceptance and ways of executing thereof is of a great importance.

\section{Implementation and development of the LEADER approach in Latvia}

The Leader approach in Latvia is being implemented since 2000. Initially it was a Baltic Rural Partnership Programme (2000-2003) funded by the Great Britain government in the Latgale region, where three local action groups (LAG) were created and 20 rural consultants and 40 community coordinators were trained, and the Baltic Sea Region Cooperation Programme supported by the Phare 2002 Small Project Fund in the Zemgale region for handling the local Rural partnership problems in the Baltic Sea region (2004-2005), where five LAGs were created, specialists trained and strategies developed.

Twenty-eight LAGs were involved in the LEADER measures (2004-2006), which encompassed $83 \%$ of the area conforming to the LEADER requirements, and $71 \%$ of population, including by involving 11 LAGs in the national programme "Acquiring of skills" and 17 LAGs in "Integrated rural development pilot strategies". Initially, only the public organizations with $100 \%$ funding intensity could apply for support (Kudins, 2010).

The LEADER approach as the measure of 4th axis of the Rural Development Programme (RDP 2007-2013) was introduced in Latvia starting 2007, and it encompassed the entire area with 40 LAGs. CLLD approach was implemented also in the Operational Programme "For the Development of Fisheries 2014-2020" as the 4th priority direction in the areas important for 24 Fishery LAGs. The 
maximum support for the RDP increased from LVL 5,000 to 20,000 with a different support intensity: up to $60 \%$ for the companies and up to $100 \%$ for the public benefit organizations.

Total funding of RDP 4th axis measures in 2007-2013 was EUR 40 million, which was $2.9 \%$ of the RDP funding (Benga E., 2016). The project applicants representing various NGOs, state authorities and local governments form $75 \%$ and have received $90 \%$ of the granted public funding. These projects based on their nature were directed at improvements to spending of free time and infrastructure.

Nevertheless, in accordance with the results of the population survey carried out by Institute of Agricultural Resources and Economics (AREI) in 2016, knowledge on LEADER still was quite low, and an opinion on economic situation and work opportunities in rural areas has improved very little since 2011. The attitude of the population to changes in the environmental, social infrastructure and service areas has, however, improved, due to the LEADER contributions. The 4th axis measures have in general reached the planned indicators both in increase of employment and in economic growth, but they are quite small for significant improvement of economic situation in rural areas (Benga E., 2016).

In the opinion of involved parties, the implementation of the LEADER approach has made a contribution in development of the area and local communities with improvement of roads, creation of meeting centres, improvement of areas and creation of infrastructure for people to spend their free time. Innovations have not been, however, introduced in majority of situations. Support to production has not been sufficient. Activities in the scope of LEADER are often carried out without a sufficient respect for the general situation and long-term perspectives (Benga E., 2016).

The previous experience of the LEADER implementation in Latvia in general prepared soil for a transfer to implementation of multi-funds, created a LAG network as a LEADER/CLDD implementation tool, covering the entire area.

Multi-fund approach was established by the EU regulations which provided for use of several funds for the implementation of local strategies. (Council EU, 2013). 2014-2020 Two-fund muti-fund approach was introduced in Latvia, which means to combine the relevant European Agricultural Fund for Rural Development (EAFRD) and European Maritime and Fisheries Fund (EMFF) measures which are implemented by the LEADER/CLLD approach.

The EU policy in the new period in general has freed EMFF from limitations and allows using the entire financing of the EU funds for reaching the strategy goals (Research for AGRI..., 2016). Still, as shown by the LDS analysis in both periods (2017-2014 and 2014-2020), LAGs do not use these opportunities and base their strategies on one or two (where applicable) funds, accordingly matching the strategy actions thereto. It poses a question on administrative capacity to satisfy the local needs, especially in the multi-fund circumstances.

\section{Quantitative results of LEADER in the period of 2014-2020}

The LEADER approach establishes a need to create solutions in the strategy based on the local development. LEADER/CLLD assessment guidelines emphasizing both the role of handling the immediate needs and also of multisectoral cooperation in reaching the local goals (European Commission, 2017). In this context, analysis of the local needs is of a great importance to define goals that may be reached by the activities funded from various sources. Analysis is carried out in the scope of the aforementioned information - to what extent such approach has been implemented 
in CLLD strategies, which answers to a question: what was the role of LAG in facilitation of the local development processes, using the LEADER approach.

CLLD strategies in accordance with the LEADER methodology are directed at defining the needs of the local society (community) and satisfaction thereof. Thus, it would be logical that the grounds for the strategies is identification of the territorial needs and defining of development goals, which is formed by understanding and prioritizing real needs of the local society (local community) and making the satisfaction thereof to be a local development goal.

It may be derived from the local needs content analysis of the LDS that the most popular associated symbol (stimulus word) is "local", which is combined with many other words and creates various associations and meanings (Table 1 ). In general, it characterizes the actions directed at local level, a location, which is a goal of LEADER. Ranking the terms, to which an adjective "local" has been most frequently added, "companies" and "business" are among the first ones, which may be explained by a special condition of the new LEADER period on moving $50 \%$ of funding to business, while the next most frequently mentioned terms are „tourism, services, NGO, cooperation, activities, products, production".

Table 1

\section{Analysis of the weaknesses described in the CLLD strategies (frequency of mentioning)}

\begin{tabular}{|l|c|c|}
\hline \multicolumn{1}{|c|}{ Associated symbol } & number & \% \\
\hline labour & 123 & 28 \\
\hline infrastructure & 114 & 26 \\
\hline knowledge, information & 94 & 21 \\
\hline public activities & 57 & 13 \\
\hline services & 35 & 8 \\
\hline other & 23 & 5 \\
\hline Total & $\mathbf{4 4 6}$ & $\mathbf{1 0 0}$ \\
\hline
\end{tabular}

Source: Authors' structure, based on SVVA strategies

An assumption can be made from the aforementioned table that the local needs are most frequently related to increasing of job opportunities, development of infrastructure, as well as availability of knowledge and information. Public activities form a less expressed yet important need. Other needs (availability of services, etc.) appear much less. It cannot, however, be clearly assessed that this is the range of the local needs, as LDS are often adjusted to the terms of the relevant funds - EAFRD and EMFF, also by including mostly the activities supported by these funds.

On the action level of LDS (according to frequency of mentioning) entrepreneurship and public infrastructure are predominant, while public activities, services and training are less frequent. Knowledge is undervalued. This could be explained partly by a structure of the LEADER program, which is created by the EU, and partly by understanding of the LEADER essence by LAGs.

The total public funding for the local LEADER development in the period of 2014-2020 via RDP is planned in the amount of EUR 79 million or $5 \%$ of the total available RDP funds for 2014-2020. Approximately $20 \%$ of that is moved toward the operation and strengthening of the LAGs, development of strategies, cooperation between areas and countries. Majority (EUR 62.8 million), however, is planned for specific projects implemented by using the LEADER approach. At least $50 \%$ of this amount must be used for initiatives intended for strengthening of the local economy (activity 19.21), while the rest - for development initiatives of the location potential (activity 19.22). 
Implementation of projects in general is active. More than 1500 projects have been paid for by the beginning of 2019, and almost 500 projects are in the implementation process. Total of $59 \%$ of the public funding available in the period has been reserved in these projects. LEADER projects have a broad territorial cover: they encompass more than 460 territorial units (or almost $80 \%$ of all cities and parishes that conform to the LEADER criteria). In general, from 587 territorial units at all projects may not be implemented in 9 cities and 4 region centres of the Republic, thus a number of eligible territorial units is 574 .

Completed projects regarding which at least one report on the recipient's economic activity indicators after the implementation of the project was submitted and available to RSS IS by the moment of data summarizing (20.08.2018) were used for the evaluation of the project results.

The main result indicator planned in the RDP for the LEADER activities is the employment created. This indicator is used to evaluate to what extent employment opportunities in the LAG areas were created by the implementation of the local development strategies.

Creation of jobs is provided for only in the activity 19.21 (business-oriented projects). Required number of created jobs is not depending on the volume of the received public funding. The only limitation is to create at least one job position which conforms to the full time employment equivalent (FTE).

Creation of jobs as a goal to be reached in the project has been selected by the smallest portion of support recipients in the relevant activity. From 186 projects, for which the report data is available, creation of jobs is planned in 45 projects. Nevertheless, jobs are actually being created also in other projects. The reported data shows 178 newly created jobs in 92 projects. In addition, the report indicators show even a slightly larger number of jobs than it was planned to achieve in the relevant projects in the third year after the project implementation.

In order to evaluate the target audience of the measure investments in facilitation of economic growth, an increase of the net turnover was also evaluated based on the information included in the project goals. Report data was gathered on 136 support recipients (some of them have several projects), of which an increase of the net turnover for 95 recipients is a target indicator. They point at a significant increase of this indicator after the implementation of projects: from EUR 1.3 million before the project to EUR 4.1 million during the $1^{\text {st }}$ year after the projects. A significant increase of the turnover is being indicated also in the second year after the project, compared to the first year. Such situation to a great extent may be explained also by a comparatively favourable economic situation in the reporting years (2016-2017). At the same time, it allows concluding that the implemented projects in general are economically successful.

Excellent result has been achieved also by calculating the net turnover changes in \% from the volume of the made investments. Increase of the net turnover in average for one recipient and the eligible costs of the relevant project have been calculated for this purpose. In average, eligible costs of each recipient's projects are in the amount of EUR 30 thousand, but the achieved increase of the turnover - EUR 48 thousand or 1.6 times higher. Also as a result of analysis of the selected project areas and actions to be taken, one can draw an indicative conclusion that selection of investments in general is well thought over and conforming to the possibilities of the local areas.

Population change is explored as a context data. According to official statistics data, in Latvia population decreased by $3.4 \%$ in 2014-2018, including in the LAGs territories by $5.2 \%$ (CSB). This is substantiated by the LAGs themselves which put a population size in the LDS as an indicator with 
decreasing trend in 8 cases from 14 LAGs used in this indicator. Demographic forecasts are even much worse. LEADER in this context should soften the effect.

Nevertheless, in formal results of the implementation process, the core role is played by the LAGs themselves, their feelings, beliefs, attitudes to their work. With the aim to find out an assessment by LAGs of their LDS impact, a survey was carried out in 2018 for the LAGs administrative leaders. The most valued are such impacts as preserving the population in the rural areas, social infrastructure, activities, job creation, especially for small and micro enterprises. Less value is attributed to social services, entrepreneurship, innovations. In the opinion of LAGs, the main importance is attributed to administrative activities - preparing of LDS, operation costs and animation activities. LAGs have a dual role - as an administrator of development and as a local facilitator of development. This was confirmed in interviews with the administration of several LAGs. Trend is to move in more administrative direction.

\section{Conclusions, proposals, recommendations}

1) Previous experience in Latvia shows better results of LEADER approach in strengthening of local potential (mainly public infrastructure, recreational possibilities etc.) than economic development. Despite that as main result indicator for the LEADER activities is the employment created, job creation is relatively insignificant for promoting employment in target territories.

2) In Latvia, the LEADER approach is developing based on the same scenarios analysed in the EU at the beginning of millennium. More detailed research is needed to specify, what are the roles of the EU, national and local level in this context.

3) Analyses show that the local development strategies are not intended to define local needs but rather oriented toward the EU financing framework. LAGs are not engaged in acquiring alternative financing, using only the EAFRD, EMFF due to lack of knowledge and motivation. In future, it would be useful to use the multi-fund approach which would facilitate development of strategies according to local (community) needs.

4) We can see that formally the LEADER programme works quite effectively and will reach the planned quantitative results. At the same time, it is not clear whether the RDP will reach the rural development aim and the Europe-2020 cohesion and social inclusion aims' qualitative aspects, where we do not have available date.

5) The main challenge for the LEADER is to find appropriate place in the local development issues in the next programme period.

\section{Bibliography}

1. European Commission (2017). Guidelines. Evaluation of LEADER/CLLD. The European Evaluation Helpdesk for Rural Development. August, 2017

2. Benga, E. (2016). Lauku attistibas programma 2007-2013. Ex-post novertejums (Ex-post Evaluation of Rural develoment Programme 2007-2013). AREI, p.300. Available at: http://www.arei.Iv/sites/arei/files/files/lapas/LAP \%202007-2013\%20expost \%20nov \%C4 \%93rt \%C4 \%93jums.pdf Accessed 12.02.2019.

3. Central Statistical Bureau of Latvia. https://www.csb.gov.Iv/lv Accessed on 20.12.2018.

4. Research for AGRI Committee - Programmes Implementing the 2015-2020 Rural Development Policy (2016). STUDY IP/B/AGRI/IC/2015-74. PE 573.448 EN

5. Pollermann, K., Raue, P., Schnaut, G. (2014a). Opportunities for a Participative Approach in Rural Development: Findings from LEADER in Mecklenburg-Vorpommern and the Requirements for Community Led Local Development. Landbauforsch Appl Agric Forestry Res 3/4 (64)127-138

6. Pollermann, K., Raue, P., Schnaut, G. (2014b). Multi-Level Governance in Rural Development: Analysing Experiences from LEADER for a Community-Led Local Development (CLLD). 54th Congress of the European Regional Science Association: „Regional Development \& Globalisation: Best Practices”, 26-29 August 2014, St. Petersburg, Russia. Available at: https://www.econstor.eu/handle/10419/104063 Accessed 12.02.2019. 
7. Krievina, A., Leimane, I., Melece, L. (2015). Analysis of Economic Aspects of Leader Projects in Latvia. Proceedings of the 2015 International Conference "Economic Science for Rural Development" No39 Jelgava, LLU ESAF, 23-24 April 2015, pp. 164-175.

8. Kudins, V. (2010) LEADER pieejas istenosana Latvija - lidzsinejas pieredzes izvertejums. Konference "Territorial Development in Latvia and Europe: the Good Practice and Future Possibilities", 2010.12.10. Latvian Rural Forum Available at: http://www.vraa.gov.Iv/uploads/Prezentacijas/V.Kudins_konference_10.12.2010.pdf Accessed 13.02.2019.

9. Svanberga, L. (2009). LEADER+ projektu istenosanas rezultati un iespejas Jelgavas rajona (Results and Possibilities of Implementation of LEADER+ projects in Jelgava District). Proceedings of the International scientific conference "Economic Science For Rural Development" //No.19, Jelgava, LLU, pp.213-219.

10.Svanberga, L., Radvila, J (2007). Lauku partneribas Zemgales regiona (Rural Partnerships in Zemgale Region). Proceedings of the International Scientific Conference "Economic Science for Rural Development" // Academy of Agricultural and Forestry Sciences of Latvia. Latvia University of Agriculture. - Jelgava, No.12 , pp.113- 121.

11. Paula, L., Zobena, A. (2007). Partneriba - inovativs diskurss Latvijas lauku attistiba. (Partnership - an Innovative Discourse in the Rural Development of Latvia) Latvijas Universitates raksti (Scientific Papers University of Latvia). - Riga, Vol.714, Sociology, pp.72-85.

12. Dargan, L., Shucksmith, M. (2008). LEADER and Innovation. European Society for Rural Sociology. Published by Blackwell Publishing, 9600 Garsington Road, Oxford OX4 2DQ, UK. Sociologia Ruralis, Vol 48, Number 3, July 2008 DOI: 10.1111/j.1467-9523.2008.00463.x

13. Marquardt, D., Möllers, J., Buchenrieder, G. (2012). Social Networks and Rural Development: LEADER in Romania. European Society for Rural Sociology. Published by Blackwell Publishing, 9600 Garsington Road, Oxford OX4 2DQ, UK Sociologia Ruralis, Vol 52, Number 4, October 2012 DOI: 10.1111/j.14679523.2012.00571.x LAGs

14. Salemink, K., Strijker, D., Bosworth, G. (2016). The Community Reclaims Control? Learning Experiences from Rural Broadband Initiatives in the Netherlands. European Society for Rural Sociology. Sociologia Ruralis, Vol 57, Number S1, November 2017 DOI: 10.1111/soru.12150

15. Shortall, S. (2004). Social or Economic Goals, Civic Inclusion or Exclusion ? An Analysis of Rural Development Theory and Practice. Sociologia Ruralis, Vol 44, No. 1, January 2004, European Society for Rural Sociology, pp.109-123.

16. Thuesen, A.A, Nielsen, N. Ch. (2014) A Territorial Perspective on EU's LEADER Approach in Denmark: the Added Value of Community-Led Local Development of Rural and Coastal Areas in a Multi-Level Governance Settings. European Countryside No.4, 2014, pp. 307-326.

17. Council EU (2013) 'COUNCIL REGULATION (EC) No 1305/2013 of 17 December 2013 on Support for Rural Development by the European Agricultural Fund for Rural Development (EAFRD) and Repealing Council Regulation (EC) No 1698/2005'. Official Journal of the European Union L347/487.

18. Cavaye, J. Understanding Community Development. Cavaye Community Development Available at: http://www.wpri.info/wp-content/uploads/2010/07/Understanding-Community-Development.pdf Accessed 05.12.2018.

19. Jankovic, D. (2012) Territorial Approach to Regional Rural Development. Economics of Agriculture 4/2012 UDC: $332.122: 338.43$

20.Vrabkova, I., Saradin, P. (2017) The Technical Efficiency Of Local Action Groups: A Czech Republic Case Study. Acta Universitatis Agriculturae Et Silviculturae Mendelianae Brunensis, Volume 65 issue 3, pp. 10651074.

21. Bosworth, G., I. Annibal, T. Carrollet al. (2015). Empowering Local Action through Neo-Endogenous Development: the Case of LEADER in England. Sociologia Ruralis 56 (3), pp. 427-449.

22. Council Regulation (EC) No. 1698/2005 of 20 September 2005 on Support for Rural Development by the European Agricultural Fund for Rural Development (EAFRD). Official Journal of the European Union, L 277/2 , 21.10.2005. 